\title{
The CADM2 gene and behavior: A phenome-wide scan in
}

\section{UK-Biobank}

\author{
Joëlle A. Pasman ${ }^{a^{*}}$ \\ Zeli Chen ${ }^{\mathrm{b} *}$ \\ Jacqueline M. Vink ${ }^{a}$ \\ Michel C. Van Den Oever ${ }^{c}$ \\ Tommy Pattij $^{\text {d }}$ \\ Taco J. De Vries ${ }^{d}$ \\ Abdel Abdellaoui ${ }^{b}$ ? \\ Karin J.H. Verweij 解
}

*shared first author

? shared last author

a Behavioural Science Institute, Radboud University Nijmegen, The Netherlands

${ }^{b}$ Department of Psychiatry, Amsterdam UMC, Amsterdam Neuroscience, University of Amsterdam,

Amsterdam, The Netherlands

${ }^{c}$ Department of Molecular and Cellular Neurobiology, Center for Neurogenomics and Cognitive Research, Amsterdam Neuroscience, Vrije Universiteit Amsterdam, Amsterdam, The Netherlands

${ }^{\mathrm{d}}$ Department of Anatomy and Neurosciences, Amsterdam UMC, Amsterdam Neuroscience, Amsterdam, The Netherlands

corresponding author:

Karin J.H. Verweij

Department of Psychiatry, Amsterdam UMC, location AMC

Meibergdreef 5

1105 AZ Amsterdam, The Netherlands 
medRxiv preprint doi: https://doi.org/10.1101/2021.04.16.21255141; this version posted April 16, 2021. The copyright holder for this preprint (which was not certified by peer review) is the author/funder, who has granted medRxiv a license to display the preprint in perpetuity. All rights reserved. No reuse allowed without permission.

karin.verweij@amsterdamumc.nl

\section{Abstract}

This phenome-wide association study examined SNP and gene-based associations of the CADM2 gene with 242 psycho-behavioral traits ( $N=12,211-453,349)$. We found significant associations with 51 traits, many more than for other genes. We replicated previously reported associations with substance use, risk-taking, and health behavior, and uncovered novel associations with sleep and dietary traits. Accordingly, CADM2 is involved in many psycho-behavioral traits, suggesting a common denominator in their biology. 
In the last 15 years, genome-wide association studies (GWASs) have identified tens of thousands of associations between genetic variants and a range of human behavioral and physical traits. One gene that has popped up surprisingly often in behavioral GWASs is the Cell Adhesion Molecule 2 gene (CADM2). Common variations (single nucleotide polymorphisms, SNPs) in the CADM2 gene have been implicated in various traits, including personality ${ }^{1}$, cognition and educational attainment ${ }^{2,3}$, risktaking behavior ${ }^{4}$, reproductive success ${ }^{5}$, autism spectrum disorders ${ }^{6}$, substance use $^{7,8}$, physical activity $^{9}$, and BMI/obesity ${ }^{10}$.

CADM2 encodes a member of the synaptic cell adhesion molecules (SynCAMs) involved in synaptic organization and signaling, suggesting that alterations in CADM2 expression affect neuronal connectivity. CADM2 is abundant in brain regions important for reward processing and addiction, including the frontal anterior cingulate cortex ${ }^{3}$, substantia nigra, and insula ${ }^{11}$. Given its common appearance in GWASs and its central role in brain functioning, CADM2 is a gene that warrants further exploration.

In this study we perform a phenome-wide association analysis (PheWAS), in which we test for associations of CADM2 (on SNP and gene level) with a comprehensive selection of psycho-behavioral phenotypes as measured in the UK Biobank cohort. Results will provide insights about whether the role of CADM2 is confined to a specific set of traits or is involved in a wider range of phenotypes. This will inform future studies on the function of CADM2 and the neurobiological underpinnings of different psycho-behavioral traits. An additional advantage is that the multiple testing burden is reduced as compared to genome-wide studies, resulting in higher power levels.

UK Biobank is a nationwide study in the United Kingdom containing phenotypic and genetic information for up to 500,000 individuals ${ }^{12}$. We analyzed 12,211 to 453,349 UK Biobank participants with European ancestry for whom genetic and phenotypic data were available. About half (54.3\%) of 
medRxiv preprint doi: https://doi.org/10.1101/2021.04.16.21255141; this version posted April 16, 2021. The copyright holder for this preprint (which was not certified by peer review) is the author/funder, who has granted medRxiv a license to display the preprint in perpetuity.

All rights reserved. No reuse allowed without permission.

the sample was female, and mean age was $M=56.8$ (range $39-73, S D=8.0$ ). We extracted the CADM2 region $250 \mathrm{~kb}$ up- and downstream (bp 84,758,133 to 86,373,579 on 3p12.1, GRCh37/hg19) and selected 4,265 SNPs with call rate $>95 \%$, minor allele frequency $>1 \%$, and $p$-value for violation of Hardy-Wein berg equilibrium of $p_{H W E}>10^{-6}$ (QC details are described in Abdellaoui, $2020^{13}$ ).

We selected 242 psychological and behavioral phenotypes from the UK Biobank with an effective sample size above $\mathrm{N}=10,000\left(\mathrm{~N}_{\text {eff }}=4 / \frac{1 / N_{\text {cases }}}{1 / N_{\text {controls }}}\right)$. In order to maximize sample size, we used the first available measurement for each individual; if the first instance was not available, we took the second, otherwise the third, etc. In addition, we included eight traits that were derived for recent genetic studies, including seven substance use traits and educational attainment in years (for an overview of all included traits, see Supplemental Table S1). Continuous phenotypes were cleaned such that theoretical implausible values were set on missing and extreme values more than 4 SDs away from the mean were winsorized at the maximum value of 4SDs. Binary and ordinal variables were left unchanged. Ordinal variables were analyzed as continuous.

The SNP-based association analyses were performed in fastGWA ${ }^{14}$, taking into account genetic relatedness. Analyses were controlled for effects of age, sex, and 25 genetic principal components (PCs, to control for genetic ancestry $\left.{ }^{15}\right)$. We used linear mixed modeling for all traits and HasemanElston regression to estimate the genetic variance component. To test the significance of CADM2associations on gene-level we conducted a MAGMA gene-based test ${ }^{16}$, which aggregates the SNP effects (regardless of direction) in a single test of association. We used the default SNP-wise mean procedure (averaging SNP effects across the gene) and checked the results of the SNP-wise top procedure for comparison (more sensitive when only a small proportion of SNPs has an effect). As significance threshold for the SNP-based test we adopted a genome-wide significance threshold of $p<5 \mathrm{E}-08$. As this is rather stringent given that we test within a single gene, we also used a significance threshold of .05 corrected for the number of independent SNPs ( $n=133$, at $R^{2}=0.10$ and $250 \mathrm{~kb}$ ) and 
the number of traits, resulting in $.05 /(133 * 242)=1.55 \mathrm{E}-06$. For the gene-based test we used a threshold of $2.62 \mathrm{E}-05$, corresponding to .05 divided by the total number of genes $(19,082)$. To provide an estimation of the effect size, we used $R^{2=} \frac{2 \beta^{2} M A F(1-M A F)}{2 \beta^{2} M A F(1-M A F)+(\operatorname{se}(\beta))^{2} 2 N M A F(1-M A F)}$, as described in ${ }^{17}$, with adaptations for binary traits as described in ${ }^{8}$.

Given that our analyses were highly powered, we assessed whether the high number of associations discovered for CADM2 was unusual or similar to those found for other genes. We therefore selected a random set of 50 genes (that were up to $50 \%$ smaller or larger in size), repeated the SNP-based analysis for these genes and compared the number of traits with significant associations. .

On the SNP-level, 38 traits reached significant associations at a genome-wide corrected $p$-value (5E08), and 61 traits at the lenient threshold of $p<1.55 \mathrm{E}-06$ (Figure 1a, Table 1). In the gene-based test, 51 out of 242 traits showed significant associations under a $p$-value of 2.62E-06 (Figure 1b, Table 1). The strongest associations were found for cognitive ability, risk taking, diet, BMI, daytime sleeping, sedentary behaviors, nervousness-like traits, reproductive traits, and substance use. There were fewer associations with occupational, traumatic experiences, social connection and non-worry related depression traits. Full SNP- and gene-based results are provided in Table S2 and S3a. Table S3b shows the gene-based results for the SNP-wise top procedure. There were some differences with the SNP-wise mean results, with only 33 significant associations and a correlation of $r=.64$ between the $p$-values from the respective tests.

<insert figure 1> 
medRxiv preprint doi: https://doi.org/10.1101/2021.04.16.21255141; this version posted April 16, 2021. The copyright holder for this preprint (which was not certified by peer review) is the author/funder, who has granted medRxiv a license to display the preprint in perpetuity.

All rights reserved. No reuse allowed without permission.

The SNPs that showed the highest number of significant trait-associations (with a maximum of 30 traits at $p<1.55 \mathrm{E}-6$, Table S4) clustered around loci at 85.53 and $85.62 \mathrm{Mb}$. As can be seen in Figure 2, most SNPs that were independently $\left(L D R^{2}<0.01\right.$, distance $\left.>250 \mathrm{~kb}\right)$ significantly associated with at least one trait cluster in the middle of the gene, a region rich in eQTLS.

<insert figure 2>

As shown in Figure $\mathrm{S} 3$, the high number of associations discovered for CADM2 was exceptional. Most of the 50 comparison genes contained fewer than 5 trait associations, with an average of 2.8 associated traits per gene and a maximum of 13 (as compared to 38 for CADM2; Table S6).

This PheWAS showed that CADM2 was involved in a wide spectrum of traits, thereby replicating and extending on previous findings. Interestingly, comparison with 50 other genes showed that this number of trait-associations was exceptionally high, emphasizing the distinctive role of CADM2 in psycho-behavioral traits. Many of the associations we found have been reported in previous literature (Table S4). However, some specific associations, such as those with specific dietary traits, daytime sleeping, number of live births, and mother's age at death have not been reported before (to our knowledge). Table S5 summarizes putatively novel SNPs for which no phenotypic associations have been reported before, providing an indication of which may be functionally involved in biological pathways. The variance explained by CADM2 was highest for lifetime cannabis use, followed by number of children fathered, age at first sexual intercourse, and risk taking. Overall, effect sizes were small (less than $0.05 \%$ for cannabis initiation), in range with what is normally found for single variants. Few associations were found in the social interaction, sleep, traumatic experiences, and occupational categories. Also, there were not many mental health traits that showed an association (8 out 53 traits). It is interesting to note the significant associations with worry and nervousness-like traits in the absence of association with (other) depression- and anxiety-related 
traits. There may be something specific to these seemingly overlapping traits, translating to distinct biological pathways.

It needs to be noted that sample sizes for the phenotypes differed substantially (from $\mathrm{N}=12,211$ to 453,349), and as such, it is possible that the pattern of associations was driven in part by differences in power. The correlation between sample size and $p$-value of the gene-based test was moderate and significant, $r=-.38$ ( $p=1.42 \mathrm{E}-9)$ showing that well-powered traits were more likely to result in a significant association. It is clear that high power was a requirement: the effect sizes of CADM2 were diminutive, as is expected for single genes and complex traits. Also, our tests were limited to the psycho-behavioral traits measured in the UK-Biobank; inclusion of more measures, such as longitudinal or non-self-report measures could contribute to a more complete picture. Still, the range of tested traits was quite broad and enabled us to discern interesting patterns.

More research is needed to elucidate these links between CADM2 and this spectrum of psychobehavioral traits in terms of neurobiological mechanisms. For example, it could be that CADM 2 is important for the learning aspects of behavior, given its role in synaptic connectivity. Speculatively, CADM2 could then contribute to reward-learning and associative learning, giving rise to risky behavior and substance use ${ }^{18}$.

This study presents the first comprehensive and rigorous test of associations between CADM2 and psycho-behavioral traits, showing strong associations for a wide range of traits (many akin to health behavior). Results could be used as starting point for future research into the function of CADM2. Research on the trait-associations and function of CADM2 will further our understanding of the biology of behavior. 


\section{Acknowledgments}

KJHV and AA are supported by the Foundation Volksbond Rotterdam. AA is supported by ZonMw grant 849200011 from The Netherlands Organisation for Health Research and Development. This project was supported by a grant from Amsterdam Neuroscience (2019). We acknowledge SURFsara for the usage of the Cartesius cluster computer (supported by NWO, EINF-457). This project was conducted under UK-Biobank application 40310.

\section{Author contributions}

$\mathrm{ZC}$ and JAP were responsible for the analyses, under supervision of AA and KJHV. JAP, ZC, AA, and KJHV wrote the manuscript. The study was conceived by KJHV and AA. Figures were created by AA. All authors read the manuscript draft and provided input.

\section{Competing interests statement}

The authors do not report any competing interests.

\section{References}

1 Boutwell, B. et al. Replication and characterization of CADM2 and MSRA genes on human behavior. Heliyon 3, e00349-e00349, doi:10.1016/j.heliyon.2017.e00349 (2017).

2 Lee, J. J. et al. Gene discovery and polygenic prediction from a genome-wide association study of educational attainment in 1.1 million individuals. Nat. Genet. 50, 1112-1121, doi:10.1038/s41588-0180147-3 (2018).

3 Ibrahim-Verbaas, C. et al. GWAS for executive function and processing speed suggests involvement of the CADM2 gene. Molecular psychiatry 21, 189 (2016).

4 Strawbridge, R. J. et al. Genome-wide analysis of self-reported risk-taking behaviour and crossdisorder genetic correlations in the UK Biobank cohort. 8, 1-11 (2018).

5 Day, F. R. et al. Physical and neurobehavioral determinants of reproductive onset and success. Nat. Genet. 48, 617-623, doi:10.1038/ng.3551 (2016). 
medRxiv preprint doi: https://doi.org/10.1101/2021.04.16.21255141; this version posted April 16, 2021. The copyright holder for this preprint (which was not certified by peer review) is the author/funder, who has granted medRxiv a license to display the preprint in perpetuity.

All rights reserved. No reuse allowed without permission.

6

7

8

9

10
Casey, J. P. et al. A novel approach of homozygous haplotype sharing identifies candidate genes in autism spectrum disorder. Hum. Genet. 131, 565-579, doi:10.1007/s00439-011-1094-6 (2012). Liu, M. et al. Association studies of up to 1.2 million individuals yield new insights into the genetic etiology of tobacco and alcohol use. Nat. Genet. 51, 237-244, doi:10.1038/s41588-018-0307-5 (2019). Pasman, J. A. et al. GWAS of lifetime cannabis use reveals new risk loci, genetic overlap with psychiatric traits, and a causal influence of schizophrenia. Nat. Neurosci. 21, 1161-1170 (2018). Klimentidis, Y. C. et al. Genome-wide association study of habitual physical activity in over 377,000 UK Biobank participants identifies multiple variants including CADM2 and APOE. Int. J. Obesity 42, 11611176, doi:10.1038/s41366-018-0120-3 (2018). Locke, A. E. et al. Genetic studies of body mass index yield new insights for obesity biology. Nature 518, 197-206, doi:10.1038/nature14177 (2015). Ndiaye, F. K. et al. The expression of genes in top obesity-associated loci is enriched in insula and substantia nigra brain regions involved in addiction and reward. 1-5 (2019).

Bycroft, C. et al. The UK Biobank resource with deep phenotyping and genomic data. Nature 562, 203209, doi:10.1038/s41586-018-0579-z (2018). Abdellaoui, A. Regional differences in reported Covid-19 cases show genetic correlations with higher socio-economic status and better health, potentially confounding studies on the genetics of disease susceptibility. 2020.2004.2024.20075333, doi:10.1101/2020.04.24.20075333 \%J medRxiv (2020). Jiang, L. et al. A resource-efficient tool for mixed model association analysis of large-scale data. Nat. Genet. 51, 1749-1755, doi:10.1038/s41588-019-0530-8 (2019). Abdellaoui, A. et al. Genetic correlates of social stratification in Great Britain. Nature Human Behaviour 3, 1332-1342, doi:10.1038/s41562-019-0757-5 (2019). de Leeuw, C. A., Mooij, J. M., Heskes, T. \& Posthuma, D. MAGMA: generalized gene-set analysis of GWAS data. PLoS Comp. Biol. 11, e1004219 (2015). Shim, H. et al. A Multivariate Genome-Wide Association Analysis of 10 LDL Subfractions, and Their Response to Statin Treatment, in 1868 Caucasians. PLoS One 10, e0120758, doi:10.1371/journal.pone.0120758 (2015). Volkow, N. D., Koob, G. F. \& McLellan, A. T. Neurobiologic Advances from the Brain Disease Model of Addiction. 374, 363-371, doi:10.1056/NEJMra1511480 (2016). 
medRxiv preprint doi: https://doi.org/10.1101/2021.04.16.21255141; this version posted April 16, 2021. The copyright holder for this preprint (which was not certified by peer review) is the author/funder, who has granted medRxiv a license to display the preprint in perpetuity.

All rights reserved. No reuse allowed without permission.

\section{Figure legends}

Figure 1. PheWAS results. Panel a) shows the subset of significant associations of the SNP-based test (61 out of 242 traits). The $\mathrm{x}$-axis shows the traits (colored by trait category) and the $\mathrm{y}$-axis the $p$-values of the association. Each dot represents a SNP association. SNPs exceeding the red horizontal line have a $p$-value significant at a genome-wide threshold of $p=5 \mathrm{E}-08$. The blue horizontal line represents the suggestive threshold of $p=1.55 \mathrm{E}-06$. Full SNP-based results are given in Supplementary Figure 1. Panel b) shows the subset of significant results of the MAGMA gene-based test (51 out of 242 traits), with $p$-values on the $y$-axis. The red dotted line represents a threshold of $p=2.62 \mathrm{E}-06$. The full gene-based results are depicted in Supplementary Figure S2.

Figure 2. The top 100 most significant SNPs for each trait with at least 1 significant SNP. The x-axis represents the base pair position, and the panel below shows information on the CADM2 transcripts as derived from https://www.ensembl.org/. 


\section{Tables}

Table 1. Phenotypes with a significant association with CADM2 according to the MAGMA gene-based test (SNP-wise mean) at $p<2.62 \mathrm{E}-06$. The top-SNP for the phenotype is given with the minor allele (A1), beta $(\beta), p$-value $(p)$, and percentage of explained variance in the respective trait $\left(\mathrm{R}^{2}(\%)\right)$. Most top-SNPs were significant at $p<1.55 \mathrm{E}-6$ (bold-faced).

\begin{tabular}{|c|c|c|c|c|c|c|c|c|}
\hline Category & Variable label & $\mathbf{N}$ & $p$ (Gene) & Top SNP & A1 & $\beta$ & $\bar{p}$ & $R^{2}(\%)$ \\
\hline Diet & Bread intake & 448,511 & $2.52 \mathrm{E}-15$ & rs2326128 & $A$ & 0.016 & 3.31E-14 & 0.013 \\
\hline Diet & Fresh fruit intake & 451,787 & $7.27 \mathrm{E}-13$ & rs12638798 & $\mathrm{T}$ & 0.015 & $1.42 \mathrm{E}-11$ & 0.010 \\
\hline Diet & Hot drink temperature & 448,701 & $3.61 \mathrm{E}-26$ & rs17023019 & $A$ & -0.012 & $5.21 E-22$ & 0.021 \\
\hline Diet & Lamb/mutton intake & 450,807 & $3.98 \mathrm{E}-08$ & rs10865611 & G & 0.007 & $3.24 \mathrm{E}-06$ & 0.005 \\
\hline Diet & Oily fish intake & 451,239 & $7.92 \mathrm{E}-14$ & rs11712915 & $\mathrm{C}$ & 0.014 & 2.95E-10 & 0.009 \\
\hline Diet & Salad / raw vegetable intake & 447,881 & 7.17E-13 & rs1248825 & A & -0.015 & 4.35E-11 & 0.010 \\
\hline Diet & Salt added to food & 453,349 & $9.63 \mathrm{E}-25$ & rs17516256 & G & 0.017 & 4.61E-20 & 0.018 \\
\hline Exercise and sedentary behavior & Length of mobile phone use & 447,851 & $4.49 \mathrm{E}-08$ & rs13092059 & $A$ & 0.023 & $2.41 \mathrm{E}-06$ & 0.005 \\
\hline Exercise and sedentary behavior & $\begin{array}{l}\text { Number of days/week of vigorous physical } \\
\text { activity } 10+\text { minutes }\end{array}$ & 431,716 & $5.98 \mathrm{E}-14$ & rs2326123 & $\mathrm{T}$ & -0.030 & $3.96 \mathrm{E}-11$ & 0.010 \\
\hline Exercise and sedentary behavior & Time spend outdoors in summer & 428,647 & $3.09 E-21$ & rs62250754 & G & 0.019 & 1.27E-18 & 0.018 \\
\hline Exercise and sedentary behavior & Time spent driving & 446,804 & $5.41 \mathrm{E}-07$ & rs7609594 & G & 0.010 & $3.39 \mathrm{E}-06$ & 0.005 \\
\hline Exercise and sedentary behavior & Time spent outdoors in winter & 428,625 & $1.24 \mathrm{E}-16$ & rs62252461 & $A$ & -0.016 & $1.23 \mathrm{E}-13$ & 0.013 \\
\hline
\end{tabular}




\begin{tabular}{|c|c|c|c|c|c|c|c|c|}
\hline Exercise and sedentary behavior & Time spent using computer & 450,226 & $2.33 \mathrm{E}-07$ & rs7642644 & $\mathrm{C}$ & -0.015 & 4.44E-07 & 0.006 \\
\hline Exercise and sedentary behavior & Time spent watching television (TV) & 449,939 & $4.53 \mathrm{E}-14$ & rs9824301 & $\mathrm{C}$ & -0.018 & 4.23E-16 & 0.015 \\
\hline Exercise and sedentary behavior & Usual walking pace & 450,769 & $2.28 \mathrm{E}-06$ & rs2290338 & $\mathrm{T}$ & -0.008 & $6.15 E-07$ & 0.006 \\
\hline Mental health & $\begin{array}{l}\text { Frequency of tiredness / lethargy in last } 2 \\
\text { weeks }\end{array}$ & 440,102 & $8.70 \mathrm{E}-08$ & rs818215 & $\mathrm{C}$ & -0.011 & $1.18 \mathrm{E}-10$ & 0.010 \\
\hline Mental health & Irritability & 433,487 & $1.24 \mathrm{E}-09$ & rs6800177 & $\mathrm{T}$ & 0.007 & 3.33E-11 & 0.010 \\
\hline Mental health & Nervous feelings & 441,742 & $3.59 \mathrm{E}-24$ & rs1449386 & $\mathrm{T}$ & -0.008 & 7.93E-19 & 0.018 \\
\hline Mental health & Neuroticism score & 367,273 & 8.97E-09 & rs818219 & C & -0.012 & 1.59E-07 & 0.008 \\
\hline Mental health & $\begin{array}{l}\text { Seen doctor (GP) for nerves, anxiety, } \\
\text { tension or depression }\end{array}$ & 450,407 & $1.30 \mathrm{E}-06$ & rs12631564 & A & 0.005 & 2.77E-06 & 0.005 \\
\hline Mental health & Suffer from 'nerves' & 436,983 & 2.37E-19 & rs7652808 & $\mathrm{T}$ & -0.007 & 2.21E-14 & 0.013 \\
\hline Mental health & Tense / 'highly strung' & 439,327 & $5.55 \mathrm{E}-12$ & rs9811546 & A & -0.005 & $5.28 \mathrm{E}-08$ & 0.006 \\
\hline Mental health & Worrier / anxious feelings & 441,805 & $1.64 \mathrm{E}-17$ & rs62250713 & A & -0.010 & $2.18 \mathrm{E}-20$ & 0.019 \\
\hline Physical health & Body mass index (BMI) & 452,241 & $2.22 \mathrm{E}-26$ & rs11915747 & G & -0.019 & $1.40 \mathrm{E}-18$ & 0.017 \\
\hline Physical health & Childhood sunburn occasions & 339,817 & 2.07E-08 & rs9880919 & A & 0.017 & 3.00E-09 & 0.010 \\
\hline Physical health & Mother's age at death & 275,917 & $4.20 \mathrm{E}-07$ & rs9843797 & $\mathrm{T}$ & -0.014 & 1.07E-07 & 0.010 \\
\hline Reproductive & Age first had sexual intercourse & 398,884 & $4.35 \mathrm{E}-27$ & rs62263912 & G & -0.026 & $1.36 E-29$ & 0.033 \\
\hline Reproductive & Lifetime number of sexual partners & 372,178 & $6.04 \mathrm{E}-13$ & rs4856598 & A & 0.014 & 3.29E-09 & 0.010 \\
\hline Reproductive & Number of children fathered & 205,843 & $4.75 \mathrm{E}-20$ & rs1368750 & $\mathrm{T}$ & 0.029 & 1.14E-19 & 0.040 \\
\hline Reproductive & Number of live births & 245,757 & $1.76 \mathrm{E}-09$ & rs1972994 & A & 0.019 & 7.41E-11 & 0.017 \\
\hline Risk taking & Risk taking & 437,513 & $2.12 \mathrm{E}-25$ & rs6762267 & $\mathrm{C}$ & 0.011 & 1.27E-30 & 0.030 \\
\hline
\end{tabular}




\begin{tabular}{|c|c|c|c|c|c|c|c|c|}
\hline Sleep & Daytime dozing / sleeping (narcolepsy) & 451,759 & $7.68 \mathrm{E}-11$ & rs960986 & $\mathrm{T}$ & -0.007 & $2.86 \mathrm{E}-11$ & 0.010 \\
\hline Sleep & Nap during day & 453,179 & $2.30 \mathrm{E}-07$ & rs3943782 & G & 0.007 & $5.89 \mathrm{E}-08$ & 0.007 \\
\hline Social interaction & Frequency of friend/family visits & 451,075 & $1.65 \mathrm{E}-06$ & rs1248860 & G & 0.011 & $1.05 E-06$ & 0.005 \\
\hline $\begin{array}{l}\text { Socioeconomic status and } \\
\text { intelligence }\end{array}$ & $\begin{array}{l}\text { Average total household income before } \\
\operatorname{tax}\end{array}$ & 390,512 & $2.37 \mathrm{E}-07$ & rs426444 & $\mathrm{T}$ & -0.015 & 4.59E-08 & 0.008 \\
\hline $\begin{array}{l}\text { Socioeconomic status and } \\
\text { intelligence }\end{array}$ & $\begin{array}{l}\text { Educational attainment transformed to } \\
\text { ISCED categories, derived for PMID } \\
27225129\end{array}$ & 449,507 & $1.21 \mathrm{E}-19$ & rs11915747 & G & 0.095 & $3.86 \mathrm{E}-18$ & 0.017 \\
\hline $\begin{array}{l}\text { Socioeconomic status and } \\
\text { intelligence }\end{array}$ & Fluid intelligence score & 233,219 & $3.25 \mathrm{E}-08$ & rs72903244 & A & -0.047 & 2.91E-08 & 0.013 \\
\hline $\begin{array}{l}\text { Socioeconomic status and } \\
\text { intelligence }\end{array}$ & Number in household & 450,782 & $3.52 \mathrm{E}-07$ & rs62250661 & $A$ & -0.010 & 7.71E-08 & 0.006 \\
\hline Substance use & Alcohol intake frequency & 453,069 & $1.05 \mathrm{E}-14$ & rs9814516 & $\mathrm{T}$ & -0.026 & $1.09 \mathrm{E}-12$ & 0.011 \\
\hline Substance use & Alcohol usually taken with meals & 235,563 & $1.27 \mathrm{E}-08$ & rs12493621 & $\mathrm{C}$ & 0.008 & $3.85 E-08$ & 0.013 \\
\hline Substance use & Average weekly beer plus cider intake & 324,232 & $6.43 \mathrm{E}-09$ & rs9824301 & $\mathrm{C}$ & -0.013 & 8.45E-09 & 0.010 \\
\hline Substance use & Average weekly red wine intake & 323,634 & $5.01 \mathrm{E}-07$ & rs382210 & G & -0.015 & 1.11E-08 & 0.010 \\
\hline Substance use & Current tobacco smoking & 453,155 & $3.76 \mathrm{E}-11$ & rs56262138 & A & -0.005 & $2.60 \mathrm{E}-08$ & 0.007 \\
\hline Substance use & Ever smoked & 451,902 & $1.01 \mathrm{E}-20$ & rs6790699 & A & 0.009 & $6.39 \mathrm{E}-16$ & 0.014 \\
\hline Substance use & Ever taken cannabis & 146,758 & $2.46 \mathrm{E}-18$ & rs62263912 & G & 0.029 & $7.44 \mathrm{E}-16$ & 0.046 \\
\hline Substance use & $\begin{array}{l}\text { Frequency of alcohol use, derived for } \\
\text { PMID } 30874500\end{array}$ & 453,070 & $1.05 \mathrm{E}-14$ & rs9814516 & $\mathrm{T}$ & -0.026 & 1.09E-12 & 0.011 \\
\hline Substance use & Frequency of drinking alcohol & 146,785 & $4.44 \mathrm{E}-07$ & rs9832119 & $\mathrm{T}$ & -0.025 & $1.06 \mathrm{E}-06$ & 0.016 \\
\hline
\end{tabular}




\begin{tabular}{|c|c|c|c|c|c|c|c|c|}
\hline Substance use & $\begin{array}{l}\text { Lifetime cannabis use, derived for PMID } \\
30150663\end{array}$ & 146,758 & $9.11 \mathrm{E}-16$ & rs62263912 & G & 0.011 & 2.63E-12 & 0.033 \\
\hline Substance use & $\begin{array}{l}\text { Light smokers, at least } 100 \text { smokes in } \\
\text { lifetime }\end{array}$ & 124,240 & $8.13 \mathrm{E}-10$ & rs62253088 & $\mathrm{T}$ & 0.011 & 2.49E-07 & 0.020 \\
\hline Substance use & Past tobacco smoking & 417,577 & $4.51 \mathrm{E}-22$ & rs6780346 & $\mathrm{C}$ & -0.024 & 7.54E-18 & 0.018 \\
\hline Substance use & $\begin{array}{l}\text { Smoking initiation, derived for PMID } \\
30643251\end{array}$ & 301,588 & $2.44 \mathrm{E}-21$ & rs62263910 & G & 0.008 & 3.26E-14 & 0.019 \\
\hline
\end{tabular}

*For binary traits, the effective sample size is given (determined using $N_{\text {eff }}=4 / \frac{1 / N_{\text {cases }}}{1 / N_{\text {controls }}}$ ). 


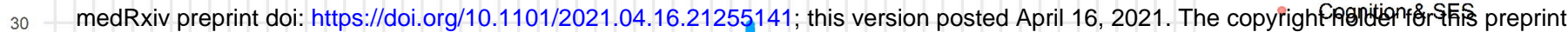
(which was not certified by peer review) is the author/funder, who has granted medRxiv a license to display the preprint in perpetuity. All rights reserved. No reuse allowed without permission.
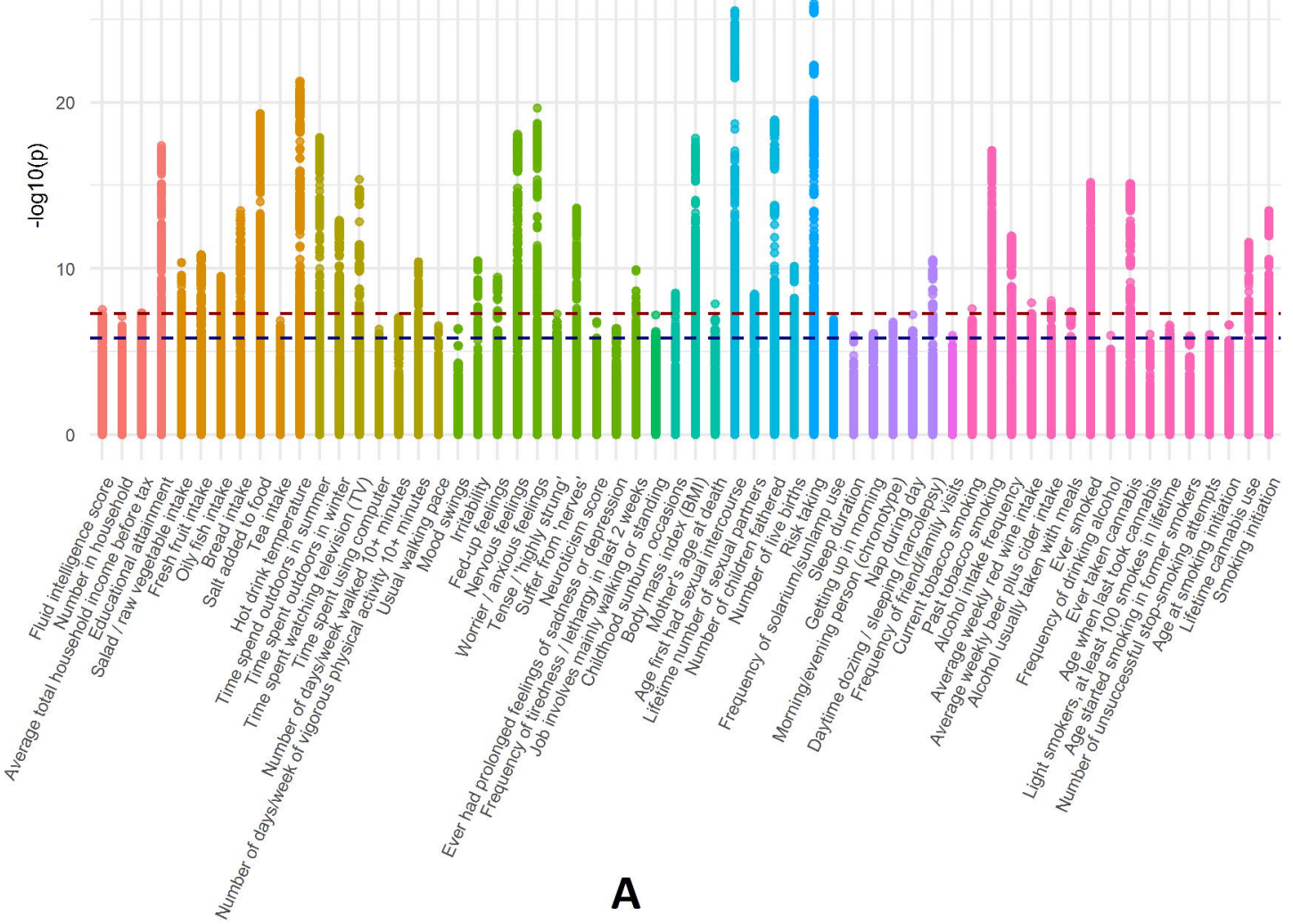

A

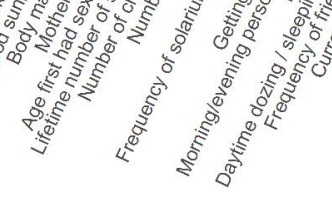

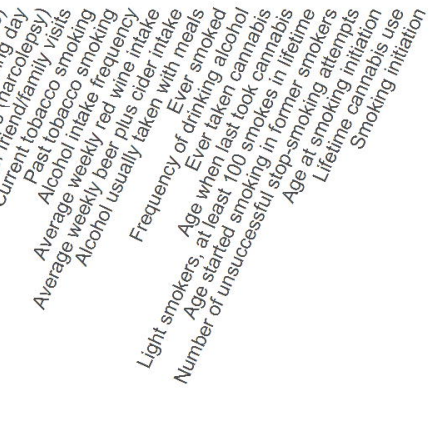

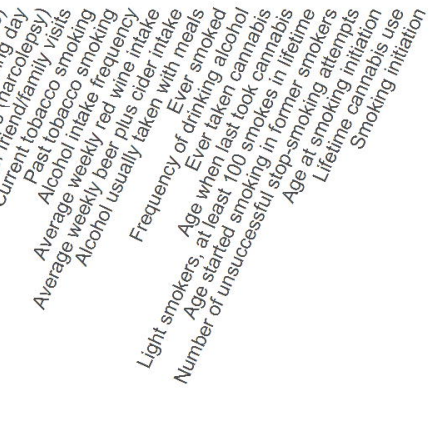

Diet

- Exercise and sedentary behavior

- Mental health

- Occupation

- Physical health

- Reproductive

- Risk taking

- Sleep

- Social interaction

- Substance use

CADM2 PHEWAS - MAGMA

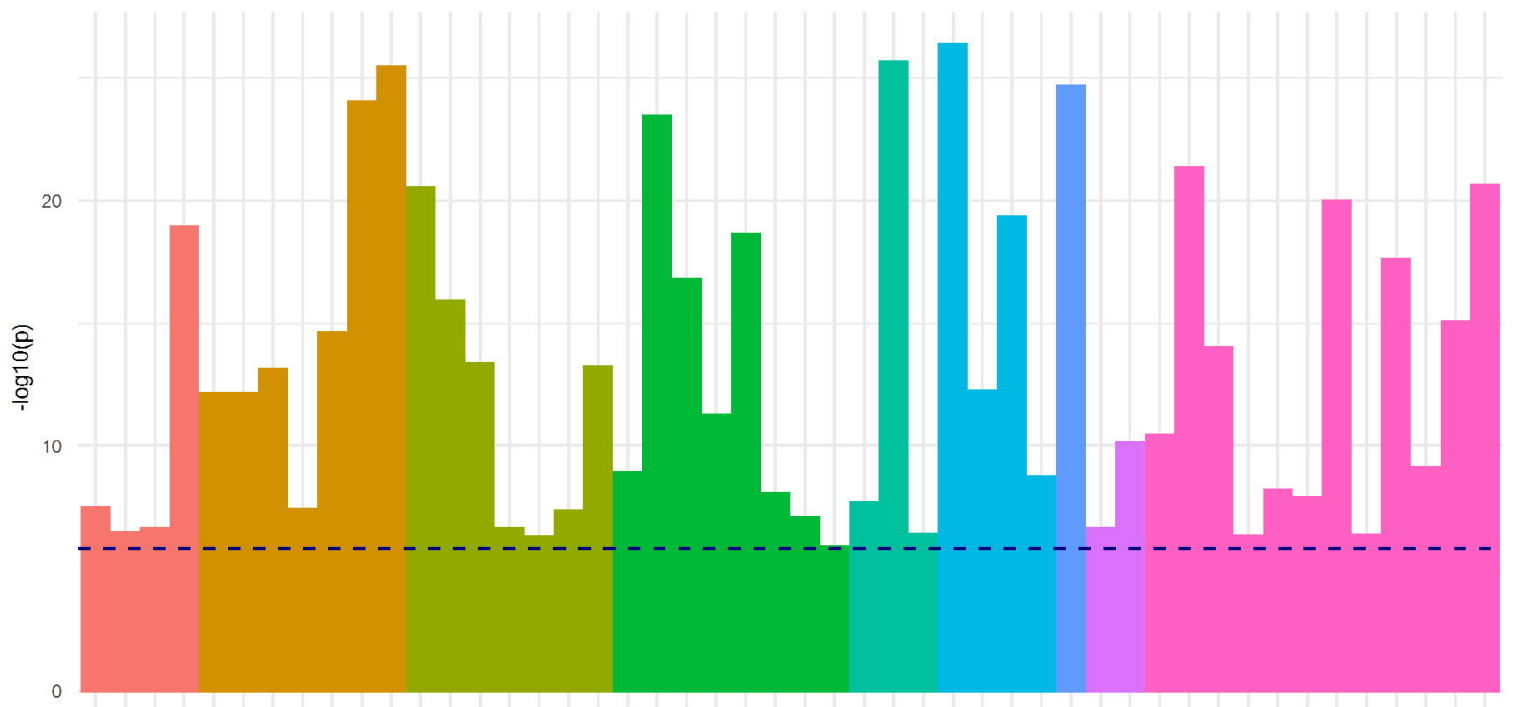


Salad / raw vegetable intake

Usual walking pace
Number of days/week of vigorous physical activity $10+$ minutes
Number of days/week walked $10+$ minutes

Time spent watching using computer

Time spent outdoors in winter
Time spend outdoors in summer

$\begin{aligned} & \text { Frequency of tiredness / lethargy in last } 2 \text { weeks } \\ &\end{aligned}$

$$
\begin{array}{r}
\text { Neuroticism score } \\
\text { Suffer from 'nerves' } \\
\text { Tense / 'highly strung' } \\
\text { Worrier / anxious feelings } \\
\text { Nervous feelings } \\
\text { Fed-up feelings } \\
\text { Irritability } \\
\text { Mood swings }
\end{array}
$$

Job involves mainly walking or standing

Mother's age at death
Body mass index (BMI)

Childhood

Number of live births
Number of children fathered

Lifetime number of sexual partners
Age first had sexual intercourse

Frequency of solarium/sunlamp use
Risk taking

Daytime dozing / sleeping (narcolepsy)

Morning/evening person (chronotype)

Getting up in morning
Sleep duration

Frequency of friend/family visits
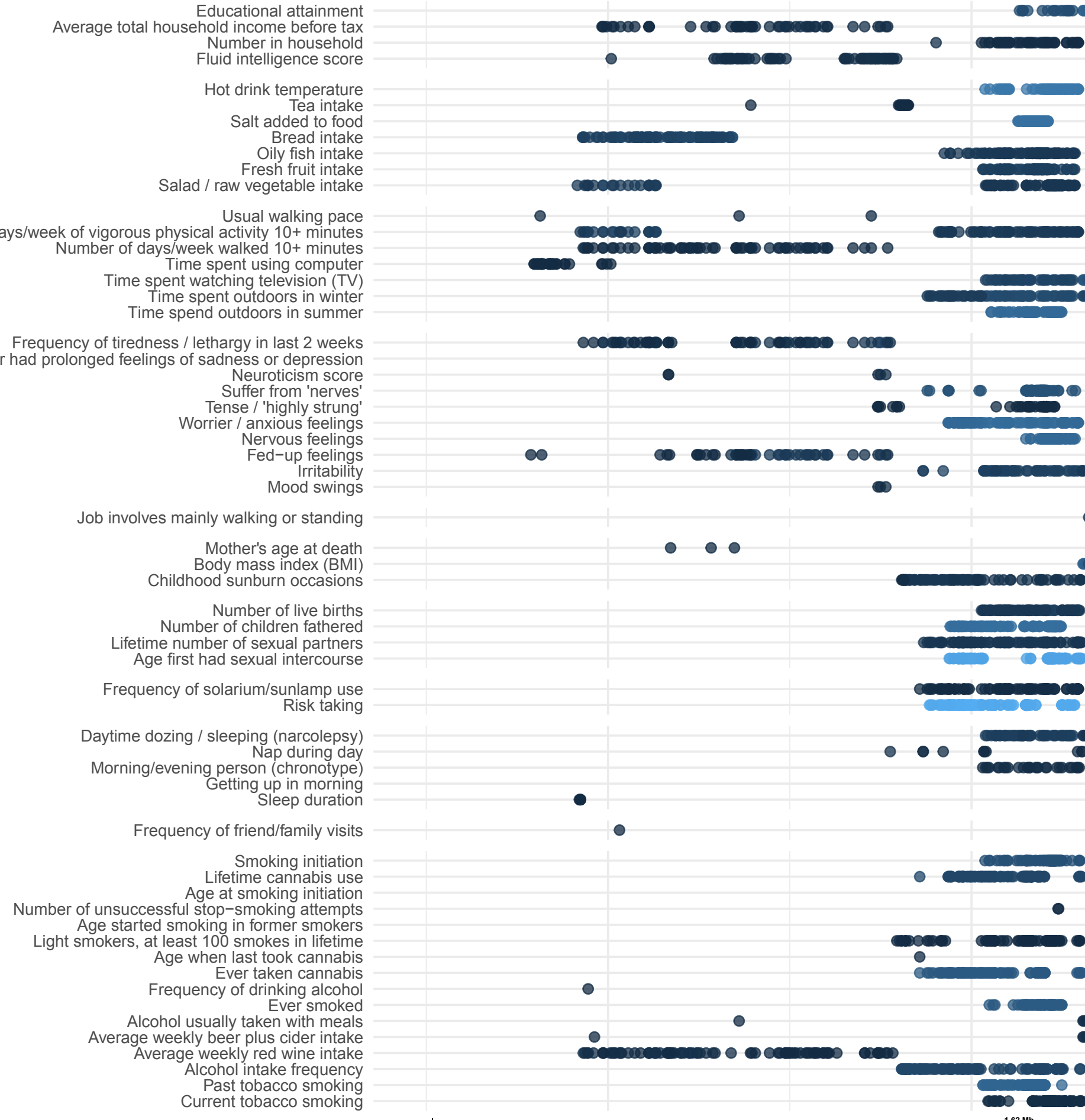

$\stackrel{0}{-\infty}$

-
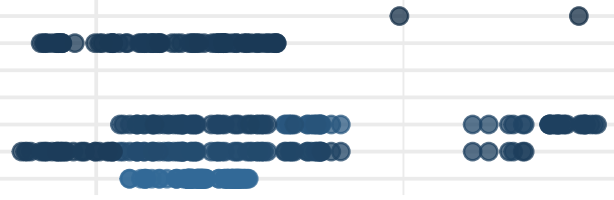

$\infty$

Cognition \& SES

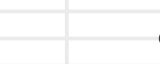

$\infty-\infty \quad 00000$

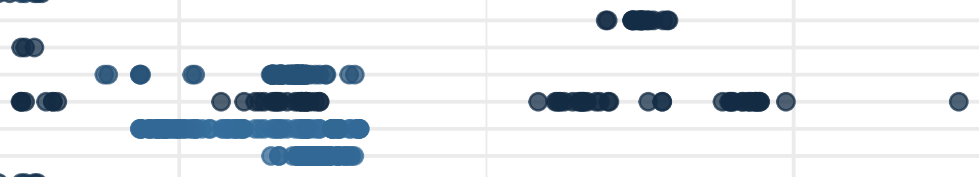

-

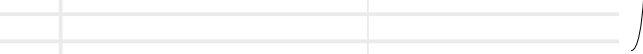

Mental health

Occupation
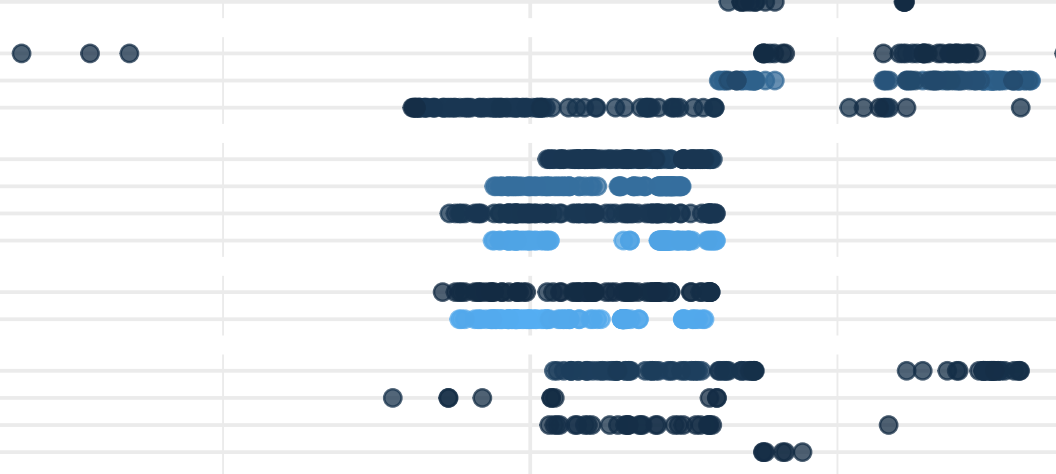

$\bullet$

-
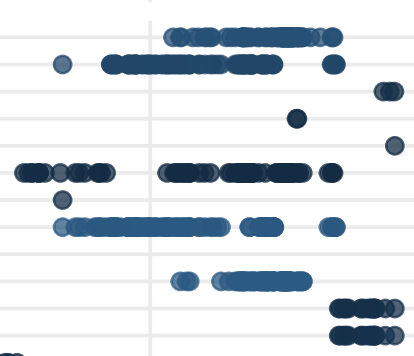

$\infty$
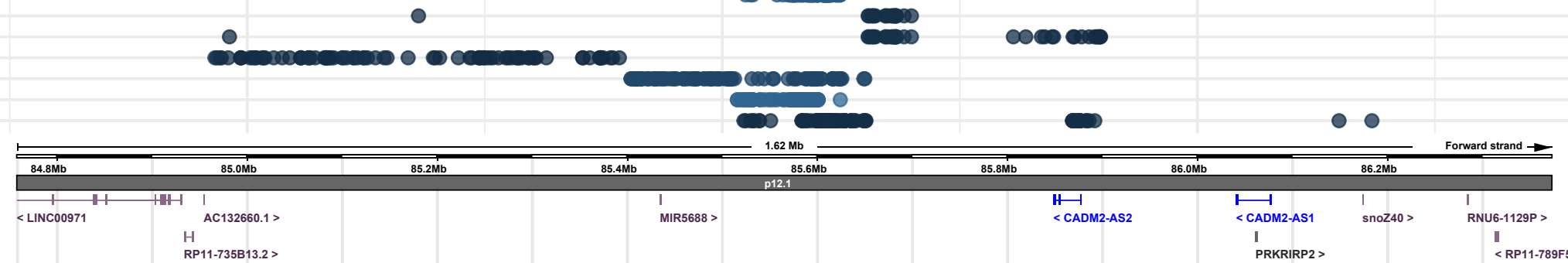

$-\log (10) P$

Chromosome bands
Genes (Comerenensive
set from GENCOOE 19)

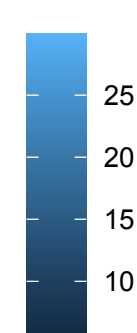

Regulatory Build

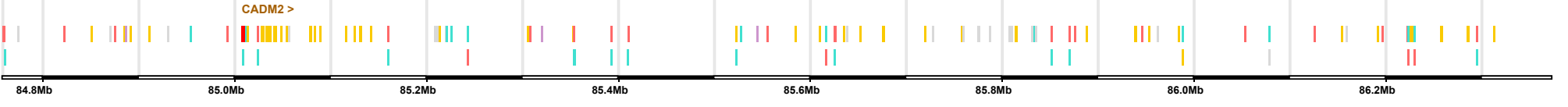

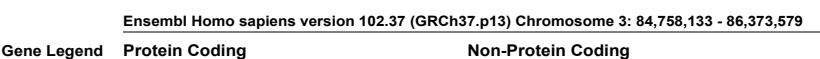

merged Ensembl/Havana

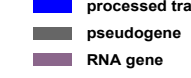

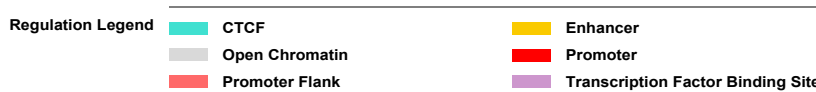

